\title{
Pengaruh Pengawasan Terhadap Disiplin Kerja Karyawan Pada Sd Islam Al-Izhar 4 Kebayoran Lama - Jakarta
}

\author{
Theobaldus Boro Tura, S.E. M.M \\ Dosen Fakultas Ekonomi Universitas Pamulang \\ Email : theobaldussr@gmail.com
}

\begin{abstract}
ABSTRAK
Sumber daya manusia adalah aset yang sangat berharga bagi setiap organisasi dan memberikan kontribusi besar kepada organisasi karena pegawai bekerja dan bertindak untuk pencapaian tujuan organisasi. Tujuan organisasi dapat dicapai melalui tingginya komitmen organisasi yang dipengaruhi oleh pengawasan dan disiplin kerja kerja. Pengelolaan sumber daya manusia yang tepat merupakan kunci keberhasilan perusahaan untuk mencapai tujuannya.

Tujuan dari penelitian ini adalah untuk mengetahui seberapa besar pengaruh pengawasan terhadap disiplin kerja karyawan yang tentunya berdampak secara operasional suatu perusahaan atau pada SD Islam Al Azhar 4 Kebayoran LamaJakarta..

Penarikan sampel dengan teknik sampel jenuh terhadap 50 responden dengan metode pengumpulan data melalui penyebaran kuesioner. Sedangkan metode analisis pengolahan data, menggunakan uji validitas, uji reliabilitas, uji korelasi product moment (korelasi pearson), uji regresi linier sederhana, uji koefisien determinasi, dan uji signifikansi koefisien korelasi (uji t).

Hasil penelitian menunjukkan bahwa variabel pengawasan (variabel $\mathrm{X}$ ) berpengaruh positif dan signifikan terhadap disiplin kerja karyawan (variabel Y) pada SD Islam Al Azhar 4 Kebayoran Lama-Jakarta. Hal ini berdasarkan hasil uji antara lain koefisien korelasi sebesar 0,830 dengan interprestasi sangat kuat, regresi linier sederhana sebesar $\mathrm{Y}=13,482+0,631 \mathrm{X}$ dengan koefisien determinasi sebesar 68,89\% serta tingkat signifikansinya sebesar 10,310.
\end{abstract}

Kata kunci : Pengawasan, Disiplin Kerja Karyawan 


\section{PENDAHULUAN}

\section{A. Latar Belakang Masalah}

Sumber Daya Manusia merupakan aspek yang sangat penting bagi perusahaan karena Sumber Daya Manusia merupakan penggerak utama perusahaan, maka sudah seharusnya perusahaan memperhatikan Sumber Daya Manusianya, terutama pada masalah motivasi, kepuasan kerja, keterlibatan kerja/penempatan tenaga kerja dan komitmen organisasi terhadap pegawai. Sehingga pengelolaan sumber daya manusia dapat berjalan sesuai dengan apa yang diharapkan perusahaan. Sumber daya manusia merupakan aset yang sangat berharga bagi perusahaan. Kesuksesan suatu perusahaan tidak hanya ditentukan oleh kualitas sumber daya manusianya saja, tetapi juga oleh tingkat kedisiplinan. Kedisiplinan karyawan dalam suatu perusahaan dapat dilihat dan diukur dari tingkat kehadiran karyawan dalam melakukan suatu pekerjaan, karena tingkat kehadiran adalah salah satu faktor yang menentukan produktivitas perusahaan.

Untuk menghasilkan sumber daya manusia yang bermutu serta penetapan sistem pengelolaan yang baik berarti perlu dilakukan perencanaan, pengadaan, pemeliharaan, pengawasan, pembinaan, pengembangan, pemuasan dan manfaat sebaik-baiknya. Dan tampaknya pada manajemen sekarang ini, bagaimanapun kompleksnya atau sederhananya suatu bentuk usaha, manusia (sumber daya manusia) yang menjadi inti sekaligus kunci keberhasilan suatu perusahaan dalam mencapai tujuan-tujuan yang telah ditetapkan. Meskipun perusahaan sebagai badan usaha dalam menjalankan usahanya telah banyak menggunakan peralatan teknologi tinggi, namun tidak akan dapat menggantikan fungsi dan kedudukan tenaga kerja. Dengan melihat hal tersebut maka penting bagi perusahaan untuk menggunakan tenaga kerja yang mempunyai produktivitas tinggi, professional serta mempunyai kesadaran akan tanggung-jawab untuk bekerja lebih baik dan maksimal sehingga tujuan perusahaan dapat tercapai. Tenaga kerja yang mempunyai pengalaman yang lebih baik akan semakin terbiasa dan terampil dalam melakukan pekerjaan sesuai dengan kemampuan yang dimiliki. Untuk itu tenaga kerja yang mempunyai pengalaman diharapkan dapat menerima dengan cepat latihan-latihan yang diberikan dalam masa percobaan sebagai calon karyawan.

Untuk mendapatkan suatu hasil pekerjaan yang baik dan bermutu tinggi maka diperlukan pengawasan yang baik. Pengawasan adalah kegiatan manajer/pimpinan yang mengusahakan agar pekerjaanpekerjaan terlaksana sesuai 
dengan rencana yang ditetapkan dan atau hasil yang dikehendaki . Pada setiap instansi pemerintah maupun swasta memerlukan pengawasan dari pihak manajer. Pengawasan ini dilakukan oleh manajer sebagai suatu usaha membandingkan apakah yang dilakukan sesuai dengan rencana yang ditetapkan. Hal ini berarti juga pengawasan merupakan tindakan atau kegiatan manajer yang mengusahakan agar pekerjaan terlaksana sesuai dengan rencana yang ditetapkan atau hasil kerja yang dikehendaki.

Pengawasan merupakan hal yang sangat penting dalam setiap pekerjaan baik dalam instansi pemerintah maupun swasta. Sebab dengan adanya pengawasan yang baik maka sesuatu pekerjaan akan dapat berjalan lancar dan dapat menghasilkan suatu hasil kerja yang optimal. Semakin lancar kerja dan disertai pengawasan yang baik maka pekerjaan itu akan berhasil dengan baik. Dengan pengawasan yang baik akan mendorong pegawai lebih giat dalam bekerja dan menghasilkan kerja yang baik pula terlebih apabila menyelesaikan pekerjaannya dengan semangat.

Pengaruh pengawasan terhadap kedisiplinan pegawai menjadi sangat penting untuk dibahas. Hal ini dimaksud untuk melihat apakah dengan diadakannya pengawasan maka dapat berpengaruh terhadap kedisiplinan pegawai pada instansi ini. Dan juga perlu ditingkatkan pengawasan yang efektif sehingga disiplin atau etos kerja pegawai dapat ditingkatkan untuk memacu produktivitas kerja pegawai yang tinggi. Apabila ada pengawasan yang efektif dari manajer maka semangat kerja akan timbul dan para pegawai akan bekerja dengan rajin dengan disiplin yang tinggi dan bertanggung jawab sehingga produktivitas kerja dapat meningkat dengan sendirinya.

Demikian halnya, SD

Islam Al Azhar 4 Kebayoran Lama. Dalam kegiatannya, salah satu faktor yang paling menentukan bagi keberhasilan tujuan organisasi adalah kepatuhan dalam melaksanakan disiplin terhadap pekerjaan dengan pengawasan secara menyeluruh . Namun adakalanya pada pelaksanaannya seringkali ditemukan adanya kelamahan dalam fungsi pengawasan yang menyebabkan karyawan sering meninggalkan tempat tanpa pemberitahuan atau mencatat alasan dan jam keluar masuk di buku ijin meinggalkan tempat. Seperti grafik dibawah ini yang menunjukan kinerja karyawan selama 4 (empat) tahun terakhir yaitu dari 2013 sampai dengan 2016 . 


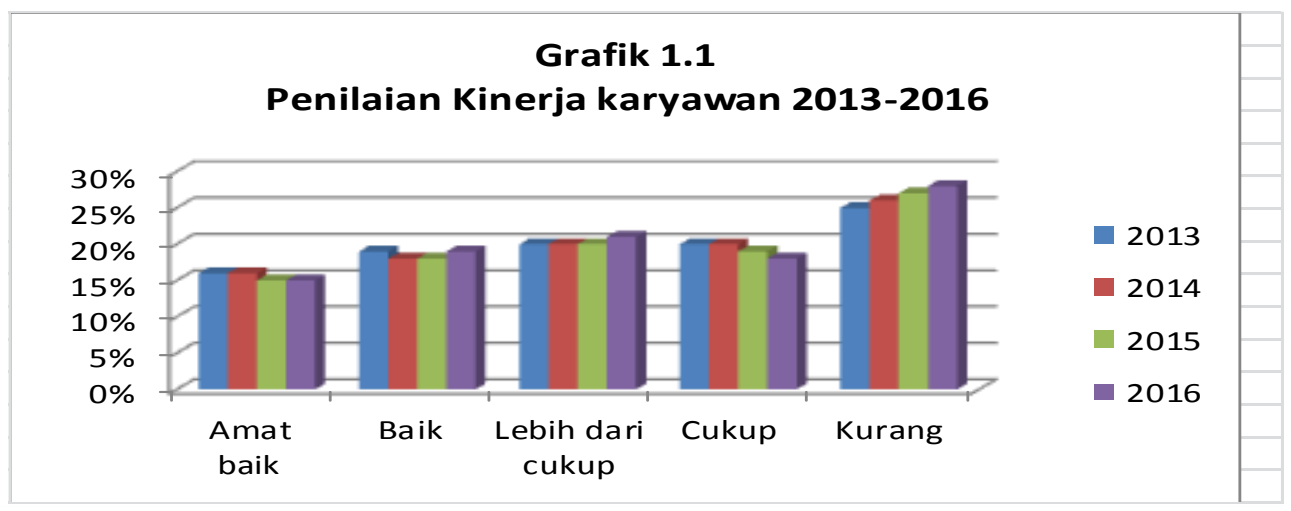

Sumber : Data primer

Kurangnya ketegasan dalam menegakan peraturan atas sikap-sikap indisipliner karyawan membuat sikap manajemen terkesan lemah dan tidak memiliki power of rule untuk membentuk karakter karyawan sehingga berimbas kepada tingginya tingkat absensi karyawan dengan berbagai alasan yang tidak mendasar. Tentu hal ini merupakan sisi negatif dari budaya kerja yang akan menurunkan kredibilitas dan kewibawaan organisasi. Gambaran tentang absensi karyawan dapat di lihat pada grafik dibawah ini selama 4 (empat) tahun terkahir yaitu dari tahun 2013 sampai dengan 2016.

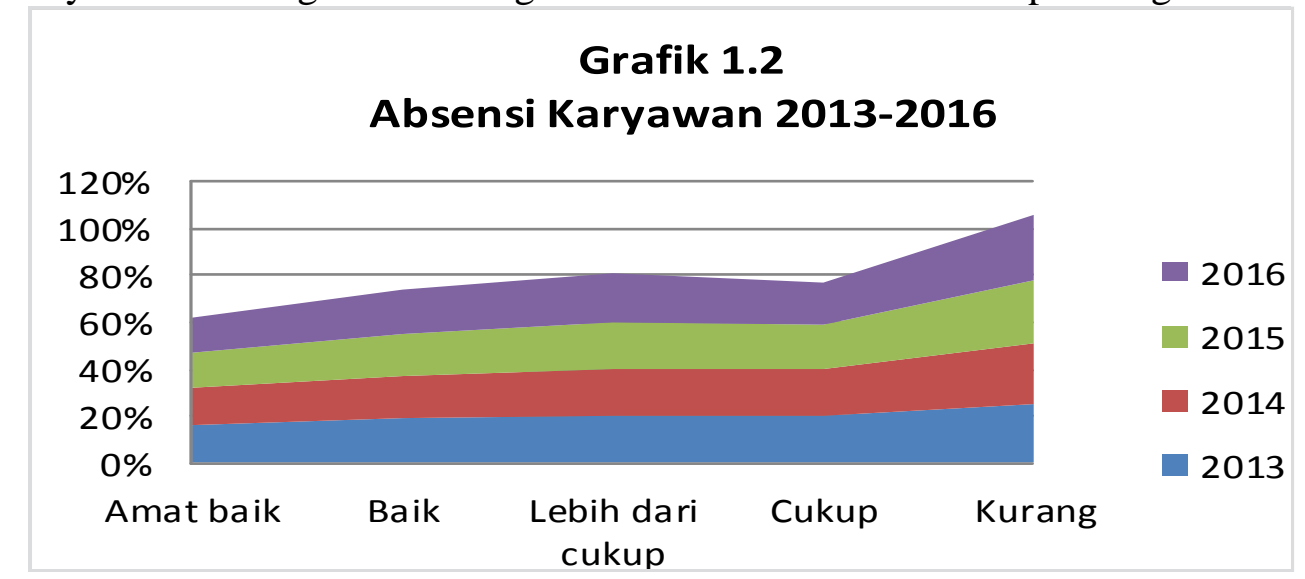

Sumber : Data primer

Kondisi lingkungan kerja yang terdiri dari ruanganruangan yang multifungsi dan dapat digunakan untuk berbagai aktifitas diluar tugas sehingga tidak terkonsentrasi sesuai plot tugas dan tanggung jawabnya maka karyawan lebih memanfaatkan hal ini disesuaikan dengan ritme kerja yang cenderung lebih santai.

Fakta yang terjadi di lapangan terhadap aktifitas karyawan yang cenderung tidak memiliki konsep dalam aktualisasi pekerjaan lebih didasarkan atas lemahnya kesadaran karyawan dalam melaksanakan tugas dan tanggung-jawabnya. Budaya organisasi belum mampu mengawal sikap dan perilaku 
yang sesungguhnya sehingga masih dirasakan jauh dari arah menuju visi dan misi organisasi.

Ketika disiplin sudah di rasakan bukan sebagai elemen pendukung yang sangat penting dan tidak adanya kesadaran murni yang lahir dari diri karyawan itu sendiri maka sangat mudah disimpulkan bahwa aktifitas yang dilakukan lebih kepada semata-mata hanya menggugurkan kewajiban dan tidak memiliki aspek orientasi dan pembentukan manajemen kerja yang lebih baik ke depan. Hal ini tidak bisa dipaksakan dan tujuan perusahaan menjadi tumpul sepanjang tidak secara bersama-sama bergerak menyatukan semangat dan misi untuk mencapai visi organisasi dengan sukses dan berkesinambungan.

Rangkaian kegiatan kerja karyawan sebagai aktualisasi dari program-program kerja yang sudah tersusun semestinya di evaluasi secara berkala untuk mengukur sejauh mana target pencapaiannya. Ketika hal ini tidak dilakukan maka akan lebih sulit menemukan alternatif dan solusi ketika ditemukan masalah di lapangan yang berhubungan dengan karyawan, konsumen dan manajemen. Penekanan (pressing) terhadap pencapaian hasil kerja sebagai bagian dari tujuan organisasi mutlak dilakukan agar karyawan memiliki semangat dan motivasi yang baik guna terciptanya iklim kerja dengan feed back saling menguntungkan antara karyawan dan perusahaan.

\section{B. Perumusan Masalah}

Berdasarkan identifikasi dan pembatasan masalah dengan mengacu pada latar belakang, maka dapat dirumuskan sebagai berikut:

1. Bagaimana pengawasan padaSD Islam Al Azhar 4 Kebayoran Lama-Jakarta?

2. Bagaimanadisiplin kerja pada SD Islam Al Azhar 4 Kebayoran Lama-Jakarta?

3. Seberapa besar pegaruh pengawasanterhadapdisipli n kerja pada SD Islam Al Azhar 4 Kebayoran LamaJakarta?

\section{METODOLOGI PENELITIAN}

\section{A. Populasi dan Sampel}

\section{Populasi}

Menurut Sugiyono (2010:15), Populasi adalah wilayah generalisasi yang terdiri atas obyek atau subyek yang mempunyai kualitas dan karakteristik tertentu yang ditetapkan oleh penelitian untuk dipelajari dan kemudian ditarik kesimpulannya.

Adapun dalam penelitian ini yang menjadi populasi adalah karyawan SD Islam Al Azhar 4 Kebayoran Lama-Jakarta sebanyak 50 orang.

\section{Sampel}

Menurut Sugiyono (2010:116). Sampel adalah suatu bagian dari jumlah yang dimiliki oleh populasi. Jumlah populasi dalam penelitian ini sebanyak 50 orang, maka pengambilan 
sampel menggunakan sampling jenuh. Sampling jenuh adalah teknik penentuan sampel bila semua anggota digunakan sebagai sampel. Hal ini dilakukan bila jumlah populasi relatif kecil, istilah lain sampel jenuh adalah sensus dengan cara pengambilan data dilakukan menyebar kepada 50 orang pegawai yang dijadikan sampel.

\section{B. Metode Pengumpulan Data}

Untuk keperluan analisis kuantitatif, maka jawaban itu dapat diberi skor, dengan menggunakan skala Likert sebagai berikut :

Tabel 2.1

Skala Likert Alternatif Jawaban Kuesioner

\begin{tabular}{|c|c|c|}
\hline No & Kategori Jawaban & Skor/Nilai \\
\hline 1 & Sangat Setuju (SS) & 5 \\
\hline 2 & Setuju (S) & 4 \\
\hline 3 & Ragu (R) & 3 \\
\hline 4 & Tidak Setuju (TS) & 2 \\
\hline 5 & Sangan Tidak Setuju (STS) & 1 \\
\hline
\end{tabular}

Sumber : Sugiyono (2012:132)

Untuk mempermudah, berikut ini disajikan tabulasi pedoman koefisien dan perbandingannya dengan hasil penelitian yang telah diolah:

Tabel 2.2

Interpretasi Koefisien Korelasi

\begin{tabular}{|c|c|}
\hline Interval Koefisien Korelasi & Interpretasi/Tingkat Hubungan \\
\hline $0,00-0,199$ & Sangat Rendah \\
$0,20-0,399$ & Rendah \\
$0,40-0,599$ & Sedang \\
$0,60-0,799$ & Kuat \\
$0,80-1,000$ & Sangat Kuat \\
\hline
\end{tabular}

Sumber: Sugiyono (2011:184)

\section{HASIL PENELITIAN DAN PEMBAHASAN}

\section{A. Hasil Distribusi Data}

Tabel 3.1

Kumulatif Distribusi Jawaban Responden Terhadap Variabel (X)

Pengawasan 


\begin{tabular}{|c|c|c|c|c|c|c|c|c|}
\hline \multirow{2}{*}{ Indikator } & \multirow{2}{*}{\multicolumn{2}{|c|}{ Pernyataan }} & \multicolumn{6}{|c|}{ Jawaban } \\
\hline & & & SS & $S$ & $\mathrm{R}$ & TS & STS & $\mathrm{Jlh}$ \\
\hline \multirow{5}{*}{$\begin{array}{l}\text { Memban- } \\
\text { dingkan }\end{array}$} & \multirow{2}{*}{\multicolumn{2}{|c|}{$\begin{array}{l}\text { Konsep yang } \\
\text { diterapkan dalam } \\
\text { bentuk program } \\
\text { kegiatan sesuai } \\
\text { dengan fakta di } \\
\text { lapangan }\end{array}$}} & 16 & 27 & 7 & 0 & 0 & 50 \\
\hline & & & $32 \%$ & $54 \%$ & $14 \%$ & $0 \%$ & $0 \%$ & $100 \%$ \\
\hline & & $\begin{array}{l}\text { Pengawasan } \\
\text { memberikan }\end{array}$ & 18 & 21 & 11 & 0 & 0 & 50 \\
\hline & 3 & $\begin{array}{l}\text { terhadap } \\
\text { pelaksanaan, } \\
\text { perencanaan, dan } \\
\text { kebijaksanaan } \\
\text { waktu yang akan } \\
\text { datang }\end{array}$ & $36 \%$ & $42 \%$ & $22 \%$ & $0 \%$ & $0 \%$ & $100 \%$ \\
\hline & & $\%$ & $34 \%$ & $48 \%$ & $18 \%$ & $0 \%$ & $0 \%$ & $100 \%$ \\
\hline \multirow{5}{*}{ Mengukur } & \multirow{2}{*}{\multicolumn{2}{|c|}{\begin{tabular}{|l} 
Perusahaan \\
melihat potensi \\
setiap individu \\
karyawan sebagai \\
aset perusahaan
\end{tabular}}} & 15 & 26 & 8 & 1 & 0 & 50 \\
\hline & & & $30 \%$ & $52 \%$ & $16 \%$ & $2 \%$ & $0 \%$ & $100 \%$ \\
\hline & \multirow[b]{2}{*}{7} & \multirow{2}{*}{$\begin{array}{l}\text { Pimpinan } \\
\text { elakukan } \\
\text { penilaian } \\
\text { terhadap kinerja } \\
\text { tiap karyawan }\end{array}$} & 12 & 18 & 17 & 3 & 0 & 50 \\
\hline & & & $24 \%$ & $36 \%$ & $34 \%$ & $6 \%$ & $0 \%$ & $100 \%$ \\
\hline & & $\%$ & $27 \%$ & $44 \%$ & $25 \%$ & $4 \%$ & $0 \%$ & $100 \%$ \\
\hline \multirow{5}{*}{$\begin{array}{l}\text { Tindakan } \\
\text { Perbaikan }\end{array}$} & \multirow[b]{2}{*}{9} & \multirow{2}{*}{$\begin{array}{l}\text { Perusahaan } \\
\text { melakukan } \\
\text { penilaian atau } \\
\text { evaluasi dari } \\
\text { pelaksanaan } \\
\text { pengawasan }\end{array}$} & 18 & 19 & 12 & 1 & 0 & 50 \\
\hline & & & $36 \%$ & $38 \%$ & $24 \%$ & $2 \%$ & $0 \%$ & $100 \%$ \\
\hline & \multirow[b]{2}{*}{2} & \multirow{2}{*}{$\begin{array}{l}\text { Pimpinan } \\
\text { memperbaiki } \\
\text { berbagai } \\
\text { penyimpangan } \\
\text { atau kesalahan } \\
\text { yang terjadi }\end{array}$} & 1 & 30 & 16 & 3 & 0 & 50 \\
\hline & & & $2 \%$ & $60 \%$ & $32 \%$ & $6 \%$ & $0 \%$ & $100 \%$ \\
\hline & & $\%$ & $19 \%$ & $49 \%$ & $28 \%$ & $4 \%$ & $0 \%$ & $100 \%$ \\
\hline Budaya & 4 & Pengawasan & 18 & 19 & 13 & 0 & 0 & 50 \\
\hline
\end{tabular}




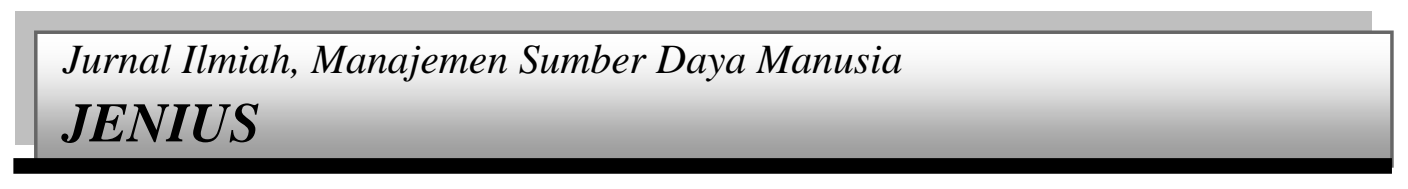

\begin{tabular}{|c|c|c|c|c|c|c|c|c|}
\hline \multirow[t]{4}{*}{ Kerja } & & $\begin{array}{l}\text { berdasarkan } \\
\text { standar prosedur } \\
\text { yang obyektif }\end{array}$ & $36 \%$ & $38 \%$ & $26 \%$ & $0 \%$ & $0 \%$ & $100 \%$ \\
\hline & \multirow{3}{*}{6} & \multirow{2}{*}{$\begin{array}{l}\text { Pengawasan } \\
\text { berorientasi pada } \\
\text { peraturan- } \\
\text { peraturan yang } \\
\text { berlaku }\end{array}$} & 12 & 15 & 19 & 4 & 0 & 50 \\
\hline & & & $24 \%$ & $30 \%$ & $38 \%$ & $8 \%$ & $0 \%$ & $100 \%$ \\
\hline & & $\%$ & $30 \%$ & $34 \%$ & $32 \%$ & $4 \%$ & $0 \%$ & $100 \%$ \\
\hline \multirow{5}{*}{$\begin{array}{l}\text { Sikap dan } \\
\text { perilaku }\end{array}$} & \multirow{2}{*}{\multicolumn{2}{|c|}{\begin{tabular}{l|l} 
& Perusahaan \\
memiliki \\
kewajiban \\
memberikan \\
apresiasi \\
maksimal \\
terhadap prestasi \\
kerja
\end{tabular}}} & 16 & 20 & 14 & 0 & 0 & 50 \\
\hline & & & $32 \%$ & $40 \%$ & $28 \%$ & $0 \%$ & $0 \%$ & $100 \%$ \\
\hline & \multirow{2}{*}{\multicolumn{2}{|c|}{$\begin{array}{l}\text { Pengawasan } \\
\text { terhadap aspek } \\
\text { loyalitas dan } \\
\text { kejujuran } \\
\text { karyawan adalah } \\
\text { prioritas }\end{array}$}} & 0 & 23 & 21 & 6 & 0 & 50 \\
\hline & & & $0 \%$ & $46 \%$ & $42 \%$ & $12 \%$ & $0 \%$ & $100 \%$ \\
\hline & & $\%$ & $16 \%$ & $43 \%$ & $35 \%$ & $6 \%$ & $0 \%$ & $100 \%$ \\
\hline \multicolumn{3}{|c|}{ Total Keseluruhan } & 126 & 218 & 138 & 18 & 0 & 500 \\
\hline \multicolumn{3}{|r|}{$\%$} & 25,2 & 43,6 & 27,6 & 3,6 & 0 & $100 \%$ \\
\hline
\end{tabular}

Sumber : Data olahan kuesioner, 2017

Berdasarkan tabel di atas, jawaban responden atas pernyataan mengenai variabel pengawasan yang diberikan oleh SD Islam Al Azhar 4 Kebayoran Lama mendapatkan jumlah total 500 dari 50 responden dengan jumlah pernyataan sebanyak 10. Dari total keseluruhan jawaban responden dapat ditarik kesimpulkan yang menjawab Sangat Setuju (SS) sebanyak 126 atau $25,2 \%$, responden menjawab Setuju (S) sebanyak 218 atau 43,6 \%, menjawab Ragu-ragu (R) sebanyak
138 atau 27,6 \%, yang menjawab Tidak Setuju (TS) 18 atau 3,6 \% dan yang menjawab Sangat Tidak Setuju (STS) sebanyak 0 atau $0 \%$.

Dari hasil tersebut diketahui bahwa jawaban responden terbanyak menjawab Setuju (S) sebesar 43,6 \% (faktor terbesar dipengaruhi oleh indikator Tindakan Perbaikan dengan persentase sebesar 49\%). Hal ini membuktikan bahwa pengawasan pada SD Islam Al Azhar 4 Kebayoran Lama 
sudah cukup baik dan optimal, namun perusahaan perlu meningkatkan lagiatau mempertahankannya karena responden terdapat responden yang menjawab Ragu-ragu (R)27,6\%,(faktor terbesar dipengaruhi oleh indikator Sikap dan Perilaku dengan presentase sebesar 49\%), dan ada yang menjawab Tidak Setuju (TS) $3,6 \%$ (faktor terbesar dipengaruhi oleh indikator Sikap dan Perilaku juga dengan presentase 12\%).

Tabel 3.2

Kumulatif Distribusi jawaban Responden Terhadap Variabel (Y)

Disiplin Kerja

\begin{tabular}{|c|c|c|c|c|c|c|c|c|}
\hline \multirow{2}{*}{ dikator } & \multirow{2}{*}{\multicolumn{2}{|c|}{ Pernyataan }} & \multicolumn{6}{|c|}{ Jawaban } \\
\hline & & & SS & $S$ & $\mathrm{R}$ & TS & STS & Jumlah \\
\hline \multirow{5}{*}{$\begin{array}{l}\text { Teladan } \\
\text { Pimpinan }\end{array}$} & \multirow{2}{*}{1} & \multirow{2}{*}{$\begin{array}{l}\text { Pimpinan } \\
\text { memberikan } \\
\text { teladan dalam hal } \\
\text { disiplin kerja }\end{array}$} & 18 & 23 & 6 & 2 & 1 & 50 \\
\hline & & & $36 \%$ & $46 \%$ & $12 \%$ & $4 \%$ & $2 \%$ & $100 \%$ \\
\hline & \multirow{2}{*}{3} & \multirow{2}{*}{$\begin{array}{l}\text { Pimpinan } \\
\text { memberikan } \\
\text { kontribusi positif } \\
\text { terhadap hasil } \\
\text { pekerjaan }\end{array}$} & 21 & 18 & 8 & 2 & 1 & 50 \\
\hline & & & $42 \%$ & $36 \%$ & $16 \%$ & $4 \%$ & $2 \%$ & $100 \%$ \\
\hline & & $\%$ & $39 \%$ & $41 \%$ & $14 \%$ & $4 \%$ & $2 \%$ & $100 \%$ \\
\hline \multirow{5}{*}{ Balas Jasa } & \multirow{2}{*}{\multicolumn{2}{|c|}{$\begin{array}{l}\text { Perusahaan } \\
\text { memberikan } \\
\text { kompensasi yang } \\
\text { sesuai dengan } \\
\text { tingkat pekerjaan }\end{array}$}} & 10 & 15 & 22 & 2 & 1 & 50 \\
\hline & & & $20 \%$ & $30 \%$ & $44 \%$ & $4 \%$ & $2 \%$ & $100 \%$ \\
\hline & \multirow{2}{*}{7} & \multirow{2}{*}{$\begin{array}{l}\text { Terdapat adanya } \\
\text { kepuasan } \\
\text { karyawan } \\
\text { terhadap hak yang } \\
\text { di dapat }\end{array}$} & 10 & 14 & 19 & 7 & 0 & 50 \\
\hline & & & $20 \%$ & $28 \%$ & $38 \%$ & $14 \%$ & $0 \%$ & $100 \%$ \\
\hline & & $\%$ & $20 \%$ & $29 \%$ & $41 \%$ & $9 \%$ & $1 \%$ & $100 \%$ \\
\hline
\end{tabular}




\begin{tabular}{|c|c|c|c|c|c|c|c|c|}
\hline \multirow{5}{*}{$\begin{array}{c}\text { Pengawasan } \\
\text { Melekat }\end{array}$} & \multirow{2}{*}{\multicolumn{2}{|c|}{$\begin{array}{l}\text { Pengawasan kerja } \\
\text { sesuai dengan } \\
\text { program dan } \\
\text { dilakukan secara } \\
\text { bertahap }\end{array}$}} & 16 & 17 & 14 & 2 & 1 & 50 \\
\hline & & & $32 \%$ & $34 \%$ & $28 \%$ & $4 \%$ & $2 \%$ & $100 \%$ \\
\hline & \multirow[t]{3}{*}{2} & \multirow{3}{*}{$\begin{array}{l}\text { Pengawasan di } \\
\text { sertai dengan } \\
\text { sarana dan } \\
\text { prasarana yang } \\
\text { cukup agar } \\
\text { penilaian lebih } \\
\text { objektif }\end{array}$} & 2 & 28 & 16 & 4 & 0 & 50 \\
\hline & & & $4 \%$ & $56 \%$ & $32 \%$ & $8 \%$ & $0 \%$ & $100 \%$ \\
\hline & & & $18 \%$ & $45 \%$ & $30 \%$ & $6 \%$ & $1 \%$ & $100 \%$ \\
\hline \multirow{5}{*}{$\begin{array}{c}\text { Sanksi } \\
\text { /Hukum an }\end{array}$} & \multirow{2}{*}{\multicolumn{2}{|c|}{\begin{tabular}{l|l} 
Sanksi hukuman \\
berperan penting \\
dalam \\
memelihara \\
kedisiplinan \\
karyawan.
\end{tabular}}} & 17 & 17 & 14 & 2 & 0 & 50 \\
\hline & & & $34 \%$ & $34 \%$ & $28 \%$ & $4 \%$ & $0 \%$ & $100 \%$ \\
\hline & \multirow{3}{*}{$\begin{array}{l}1 \\
5 \\
5 \\
1 \\
b \\
1 \\
1\end{array}$} & $\begin{array}{l}\text { Berat ringanya } \\
\text { sanksi hukuman } \\
\text { yang akan } \\
\text { ditetapkan ikut }\end{array}$ & 14 & 20 & 14 & 2 & 0 & 50 \\
\hline & & $\begin{array}{l}\text { baik buruknya } \\
\text { kedisiplinan } \\
\text { karyawan. }\end{array}$ & $28 \%$ & $4 \%$ & $28 \%$ & $4 \%$ & $0 \%$ & $100 \%$ \\
\hline & & $\%$ & $31 \%$ & $37 \%$ & $28 \%$ & $4 \%$ & $0 \%$ & $100 \%$ \\
\hline Ketegasan & 8 & $\begin{array}{l}\text { Ketegasan } \\
\text { memiliki efek } \\
\text { positif terhadap } \\
\text { pelaksanaan }\end{array}$ & 18 & 15 & 14 & 2 & 1 & 50 \\
\hline
\end{tabular}




\begin{tabular}{|c|l|c|c|c|c|c|c|}
\hline & pekerjaan & $36 \%$ & $3 \%$ & $28 \%$ & $4 \%$ & $2 \%$ & $100 \%$ \\
\hline & \begin{tabular}{|l} 
Pimpinan yang \\
berani bertindak \\
tegas menerapkan \\
hukuman yang \\
indisipliner akan \\
disegani dan \\
diakui \\
kepemimpinannya \\
oleh bawahan.
\end{tabular} & $6 \%$ & 25 & 17 & 5 & 0 & 50 \\
\cline { 2 - 8 } & $\%$ & $21 \%$ & $40 \%$ & $31 \%$ & $7 \%$ & $1 \%$ & $100 \%$ \\
\hline Total Keseluruhan & 129 & 192 & 144 & 30 & 5 & 500 \\
\hline \multirow{2}{*}{$\%$} & 25,8 & 38,4 & 28,8 & 6 & 1 & $100 \%$ \\
\hline
\end{tabular}

Dari data kontribusi jawaban diatas dapat diketahui responden

terbanyak menjawab Setuju (S) sebesar 25,8\% (Faktor terbesar dipengaruhi oleh indikator Pengawasan Melekat dengan presentase sebesar 45\%), Hal ini mengisyaratkan bahwa disiplin kerja pada SD Islam Al Azhar 4 Kebayoran Lama sudah cukup baik dan optimal, namun perlu ditingkatkan lagi karena terdapat responden yang menjawab Raguragu (R) sebesar 28,8\% (faktor terbesar dipengaruhi oleh indikator Balas Jasa dengan presentase sebesar $41 \%$ ), dan yang menjawab Tidak Setuju (TS)6\% (faktor terbesar dipengaruhi oleh indikator Balas Jasa dengan presentase sebesar 9\%), dan yang menjawab Sangat Tidak Setuju
(STS) sebesar 1\% (faktor terbesar dipengaruhi oleh indikator Teladan Pimpinan dengan presentase sebesar $2 \%$ ).

B. Hasil Analisis Data

1. Korelasi Product Moment

Dalam menganalisa pengaruh Pengawasan terhadap Disiplin Kerja karyawan SD Islam Al Azhar 4 Kebayoran Lama Penulis menggunakan metode korelasi sederhana.

Dari hasil pengumpulan kuesioner sebanyak 50 responden dengan kuesioner Pengawasan (X) dan Disiplin Kerja (Y) sebanyak masingmasing 10 pernyataan dan diperoleh data sebagai berikut : 
Tabel 4.26

Analisa Pengaruh Pengawasan terhadap Disiplin Kerja

\begin{tabular}{|c|c|c|c|c|c|}
\hline No & $X$ & $Y$ & $X^{2}$ & $Y^{2}$ & $\mathrm{XY}$ \\
\hline 1 & 33 & 37 & 1089 & 1369 & 1221 \\
\hline 2 & 35 & 33 & 1225 & 1089 & 1155 \\
\hline 3 & 45 & 42 & 2025 & 1764 & 1890 \\
\hline 4 & 42 & 40 & 1764 & 1600 & 1680 \\
\hline 5 & 43 & 42 & 1849 & 1764 & 1806 \\
\hline 6 & 40 & 42 & 1600 & 1764 & 1680 \\
\hline 7 & 46 & 39 & 2116 & 1521 & 1794 \\
\hline 8 & 39 & 39 & 1521 & 1521 & 1521 \\
\hline 9 & 39 & 34 & 1521 & 1156 & 1326 \\
\hline 10 & 42 & 39 & 1764 & 1521 & 1638 \\
\hline 11 & 40 & 42 & 1600 & 1764 & 1680 \\
\hline 12 & 33 & 34 & 1089 & 1156 & 1122 \\
\hline 13 & 30 & 31 & 900 & 961 & 930 \\
\hline 14 & 41 & 36 & 1681 & 1296 & 1476 \\
\hline 15 & 29 & 35 & 841 & 1225 & 1015 \\
\hline 16 & 31 & 35 & 961 & 1225 & 1085 \\
\hline 17 & 47 & 43 & 2209 & 1849 & 2021 \\
\hline 18 & 41 & 43 & 1681 & 1849 & 1763 \\
\hline 19 & 41 & 41 & 1681 & 1681 & 1681 \\
\hline 20 & 40 & 39 & 1600 & 1521 & 1560 \\
\hline 21 & 48 & 42 & 2304 & 1764 & 2016 \\
\hline 22 & 36 & 37 & 1296 & 1369 & 1332 \\
\hline 23 & 39 & 36 & 1521 & 1296 & 1404 \\
\hline 24 & 42 & 40 & 1764 & 1600 & 1680 \\
\hline 25 & 40 & 38 & 1600 & 1444 & 1520 \\
\hline 26 & 31 & 33 & 961 & 1089 & 1023 \\
\hline 27 & 31 & 35 & 961 & 1225 & 1085 \\
\hline 28 & 31 & 31 & 961 & 961 & 961 \\
\hline 29 & 31 & 32 & 961 & 1024 & 992 \\
\hline 30 & 47 & 47 & 2209 & 2209 & 2209 \\
\hline 31 & 43 & 38 & 1849 & 1444 & 1634 \\
\hline 32 & 45 & 39 & 2025 & 1521 & 1755 \\
\hline 33 & 40 & 41 & 1600 & 1681 & 1640 \\
\hline 34 & 46 & 45 & 2116 & 2025 & 2070 \\
\hline 35 & 34 & 34 & 1156 & 1156 & 1156 \\
\hline 36 & 41 & 38 & 1681 & 1444 & 1558 \\
\hline
\end{tabular}




\begin{tabular}{|c|c|c|c|c|c|}
\hline No & $\mathrm{X}$ & $\mathrm{Y}$ & $\mathrm{X}^{2}$ & $\mathrm{Y}^{2}$ & $\mathrm{XY}$ \\
\hline 37 & 42 & 39 & 1764 & 1521 & 1638 \\
\hline 38 & 38 & 37 & 1444 & 1369 & 1406 \\
\hline 39 & 36 & 33 & 1296 & 1089 & 1188 \\
\hline 40 & 33 & 32 & 1089 & 1024 & 1056 \\
\hline 41 & 27 & 33 & 729 & 1089 & 891 \\
\hline 42 & 32 & 31 & 1024 & 961 & 992 \\
\hline 43 & 47 & 47 & 2209 & 2209 & 2209 \\
\hline 44 & 43 & 41 & 1849 & 1681 & 1763 \\
\hline 45 & 45 & 43 & 2025 & 1849 & 1935 \\
\hline 46 & 42 & 39 & 1764 & 1521 & 1638 \\
\hline 47 & 46 & 46 & 2116 & 2116 & 2116 \\
\hline 48 & 35 & 37 & 1225 & 1369 & 1295 \\
\hline 49 & 40 & 40 & 1600 & 1600 & 1600 \\
\hline 50 & 44 & 35 & 1936 & 1225 & 1540 \\
\hline Total & 1952 & 1905 & 77752 & 73471 & 75346 \\
\hline
\end{tabular}

Dari data diatas, penulis gunakan untuk mengetahui hubungan antara Variabel X (Pengawasan) dengan Variabel Y (Disiplin Kerja), dengan menggunakan rumus korelasi sebagai berikut :

$$
\begin{aligned}
& \mathrm{r}= \\
& \frac{n\left(\sum X Y\right)-\left(\sum X\right)}{\left.\sqrt{\left\{n \cdot \sum X^{2}\right.}-\left(\sum X\right)^{2}\right\} \cdot\{(n .2} \\
&=\frac{(50.75}{\sqrt{\{(50 \cdot 77752)}} \\
&=\frac{37}{\sqrt{(3887600-38}} \\
&=\frac{48740}{\sqrt{77296.44525}} \\
&=\frac{48740}{\sqrt{3441604400}} \\
&=\frac{48740}{58665,188} \\
&=0,830
\end{aligned}
$$$$
\frac{n\left(\sum X Y\right)-\left(\sum X\right) \cdot\left(\sum Y\right)}{\sqrt{\left\{n \cdot \sum X^{2}-\left(\sum X\right)^{2}\right\} \cdot\left\{\left(n \cdot \sum Y^{2}\right)-\left(\sum Y\right)^{2}\right\}}}
$$$$
(50.75346)-(1952.1905)
$$

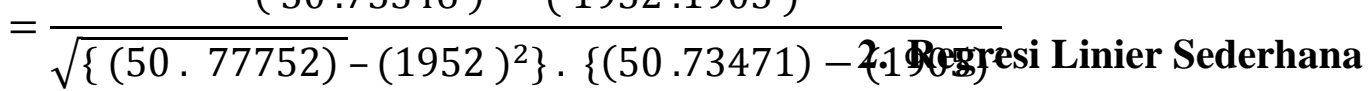$$
3767300-3718560
$$

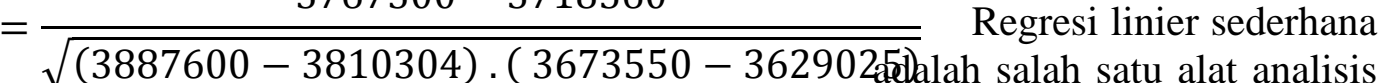$$
48740 \text { salah satu alat analisis }
$$

Dari hasil analisis perhitungan menggunakan rumus koefisien korelasi Pearson ada hubungan korelasi positif antara
Pengawasan dengan Disiplin Kerja karyawan yaitu sebesar $r=0,830$ yang termasuk kategori Sangat Kuat

$$
(0,80-0,100) \text {, maka }
$$
untuk mengetahui seberapa besar pengaruh Pengawasan terhadap Disiplin Kerja adalah dengan menggunakan koefisien determinasi. yang digunakan untuk mengetahui seberapa besarnya pengaruh variabel independen (X) yakni Pengawasan terhadap variabel dependen (Y) yakni Disiplin Kerja, adapun rumus regresi linier sederhana adalah sebagai berikut :

Dalam rumus regresi linier tersebut, penulis harus 
mencari nilai koefisien a dan $b$ terlebih dahulu. Nilai $a$ dan $b$ dapat dicari menggunakan rumus sebagai berikut :

a. $\quad=\frac{(\Sigma y)\left(\Sigma x^{2}\right)-(\Sigma x)(\Sigma x y)}{n\left(\Sigma x^{2}\right)-(\Sigma x)^{2}}$

$=\frac{(1905)(77752)-(1952)(75346)}{50(77752)-(1952)^{2}}$

$=\frac{148117560-147075392}{3887600-3810304}$

$=\frac{1042168}{77296}$

$=13,482$

b. $\quad=\frac{n(\Sigma x y)-(\Sigma x)(\Sigma y)}{n\left(\Sigma x^{2}\right)-(\Sigma x)^{2}}$

$=\frac{50(75346)-(1952)(1905)}{50(77752)-(1952)^{2}}$

$=\frac{3767300-3718560}{3887600-3810304}$

$=\frac{48740}{77296}$

$=0,631$

\section{Koefisien Determinasi}

Selanjutnya untuk mengetahui seberapa besar pengaruh pengawasan terhadap disiplin kerja karyawan digunakan rumus koefisien penentu atau koefisien Determinasi sebagai berikut :

$R$ ( Koefisien Determinasi )

$$
\begin{aligned}
& =r^{2} \times 100 \% \\
& =(0,830)^{2} \times 100 \% \\
& =0,6889 \times 100 \% \\
& =68,89 \%
\end{aligned}
$$

Hal ini membuktikan bahwa besarnya pengaruh pengawasan terhadap disiplin kerja karyawan sebesar 68,89
$\%$ dan sisanya sebesar 31,11

$\%$ dipengaruhi oleh beberapa faktor lain.

\section{Uji Signifikansi}

Berdasarkan hasil perhitungan di atas, maka penulis melakukan pengujian hipotesa dengan cara membandingkan t-tabel dengan t-hitung. Nilai t tabel ditentukan berdasarkan tingkat signifikan $(\alpha)$ yang digunakan dan derajat kebebasan $\quad(\mathrm{df}=\mathrm{n}-2)$ yang besarnya tergantung dari jumah sampel (n). Taraf nyata yang penulis gunakan sebesar $0,05(5 \%)$.

Rumus $\mathrm{t}$ hitung adalah sebagai berikut :

$$
\begin{aligned}
t \quad & =r \frac{\sqrt{n-2}}{\sqrt{1-r^{2}}} \\
& =0,830 \frac{\sqrt{50-2}}{\sqrt{1-0,830^{2}}} \\
& =0,830 \frac{\sqrt{48}}{\sqrt{1-0,6889}} \\
& =0,830 \frac{\sqrt{48}}{\sqrt{0,3111}} \\
& =0,830 \frac{6,9282}{0,5577} \\
& =0,830 \cdot 12 \cdot 4228 \\
& =10 \cdot 310
\end{aligned}
$$

Pengambilan keputusan menggunakan angka pembanding $\mathrm{t}$ tabel dengan kriteria sebagai berikut :

Jika $t_{\text {hitung }} \geq$ dari $t_{\text {tabel, }}$ maka signifikan.

Jika $t_{\text {hitung }} \leq$ dari $t_{\text {tabel, }}$ maka tidak signifikan.

Sehingga berdasarkan hasil pengujian rumus di atas maka $t_{\text {hitung }}>t_{\text {tabel }}$ yaitu 10,310 $>2,4$ yang artinya bahwa $\mathrm{H}_{0}$ 
ditolak dan $\mathrm{H}_{1}$ diterima, artinya Pengawasan (X) mempunyai pengaruh yang signifikan terhadap Disiplin Kerja karyawan (Y).

Dari hasil perhitungan di atas, maka diperoleh persamaan regresi sebagai berikut :

$$
Y=13,482+0,631 X
$$

$$
\text { Dapat dijelaskan }
$$

sebagai berikut :

a. Nilai konstanta sebesar 13,482 menyatakan bahwa jika $X=0$ maka nilai $\mathrm{Y}=13,482$

b. Nilai koefisien regresi variabel Pengawasan (X) terhadap variabel Disiplin Kerja (Y) adalah sebesar 0,631. Hal ini berarti jika variabel Pengawasan (X) naik satu, maka akan meningkatkan variabel Disiplin Kerja sebesar 0,631 .

\section{Pembahasan}

Atas dasar hasil dari penelitian yang dilakukan oleh penulis, terdapat pengaruh pengawasan yang sangat signifikan terhadap disiplin kerja karyawan pada SD Islam Al Azhar 4 Kebayoran Lama.Hal ini dapat dilihat dari hasil analisis koefisien korelasi yang merupakan angka yang menunjukkan arah dan kuatnya hubungan antar dua variabel atau lebih, sehingga dalam tabel pedoman interpretasi koefisien korelasi dinyatakan pengaruh pengawasan sangat signifikanatau sangat kuat pengaruhnya terhadap disiplin kerja karyawan.

Sementara itu, dari hasil perhitungan koefisien determinasi dapat disimpulkan bahwa variabel independen dalam penelitian ini mampu menerangkan bahwapengawasan pada SD Islam Al Azhar 4 Kebayoran Lama meiliki jumlah reduksi yang besar sedangkan sisanya dijelaskan oleh variabel lain yang tidak dimasukan dalam penelitian ini.

Dalam hasil perhitungan analisis regresi linier sederhana dapatdi prediksi nilai variabel dependen berdasarkan nilai variabel independen ketika nilai variabel pengawasan $(\mathrm{X})$ naik satu (Satuan), maka dapat meningkatkan variabel disiplin kerja (Y) . Dan dari hasil perhitungan uji hipotesis dapat disimpulkan $t_{\text {hitung }} \geq$ $t_{\text {tabel }}$ dengan nilai yang sinifikan.

\section{KESIMPULAN DAN SARAN}

\section{A. Kesimpulan}

Berdasarkan hasil penelitian dan pembahasan yang berkaitan dengan pengaruh pengawasan terhadap disiplin kerja karyawan SD Islam Al Azhar 4 Kebayoran Lama, maka dapat ditarik kesimpulan:

1. Peran dan fungsi pengawasan yang dilakukan oleh SD Islam Al Azhar 4 Kebayoran Lama sudah cukup baik dan 
optimal baik dari perspektif karyawan mauapun manajemen, didasarkan pada hasil jawaban responden dengan persentase dan jumlah responden terbanyak menjawab Setuju (S) dan terendah menjawab Sangat Tidak Setuju (STS) dengan indikator tertinggi ditunjukkan oleh Tindakan Perbaikan yang mencapai 98\% dan indikator terendah ditunjukkan oleh Budaya Kerja.

2. Disiplin kerja karyawan pada SD Islam Al Azhar 4 Kebayoran Lama mendapat respon yang baik dari karyawan didasarkan pada hasil jawaban responden dengan presentase tertinggi menjawab Setuju (S) dan terendah menjawab Sangat Tidak Setuju (STS) dengan indikator tertinggi ditunjukkan oleh pengawasan melekat dan indikator terendah ditunjukkan oleh Balas Jasa.

3. Berdasarkan hasil analisis perhitungan menggunakan rumus koefisien korelasi Pearson ada hubungan korelasi positif antara Pengawasan dengan Disiplin Kerja karyawan yaitu sebesar $\mathrm{r}=0,830$ sehingga termasuk kategori Sangat Kuat $(0,80-$ 0,100), diperkuat dengan hasil kalkulasi perhitungan koefisien penentu atau determinasi yang mencapai $68,89 \%$, hal ini membuktikan bahwa besarnya pengaruh pengawasan terhadap disiplin kerja karyawan sebesar 68,89 $\%$ dan sisanya sebesar 31,11 $\%$ dipengaruhi oleh beberapa faktor lain.

Berdasarkan hasil perhitungan tersebut, maka pengujian hipotesa dilakukan dengan cara membandingkan ttabel dengan t-hitung. Nilai ttabel ditentukan berdasarkan tingkat signifikan $(\alpha)$ yang digunakan dan derajat kebebasan $\quad(\mathrm{df}=\mathrm{n}-2) \quad$ yang besarnya tergantung dari jumah sampel (n). Sehingga berdasarkan hasil pengujian rumus di atas maka $t_{\text {hitung }}>t_{\text {tabel }}$ yaitu 10,310 > 2,4 yang artinya bahwa Pengawasan (X) mempunyai pengaruh yang signifikan terhadap Disiplin

B. Saran

Kerja karyawan (Y).

Berdasarkan kesimpulan diatas dan hasil penelitian yang dilakukan maka dapat dikemukakan saran - saran sebagai berikut:

1. Pengawasan yang dilakukan pada SD Islam Al Azhar 4 Kebayoran Lama sudah cukup baik, tetapi harus lebih ditingkatkan atau dipertahankan melalui tindakan perbaikan yang terus dilakukan dalam tata kelola manajemen agar tumbuh etos kerja yang lebih baik dari tingkat bawah sampai atas sehingga dengan sendirinya terbentuk budaya kerja yang kondusif dan pada akhirnya mampu melahirkan semangat dan motivasi tertinggi guna 
pencapaian keberhasilan perusahaan.

2. Disiplin kerja pada SD Islam Al Azhar 4 Kebayoran Lama saat ini cukup baik namun perlu adanya pengawasan yang lebih melekat dan konsisten untuk meningkatkan kualitas kinerja karyawan yang di dukung oleh balas jasa dan perhatian yang baik agar tumbuh semangat dan motivasi yang lahir dari sebuah kesadaran bersama.

3. Pengawasan dan disiplin kerja karyawan adalah dua sisi yang sangat penting dan urgen pengaruhnya karenanya dibutuhkan peran yang serius untuk menumbuhkan keduanya sebagai sebuah motor penggerak kemajuan dan indikator pencapaian tujuan. SD Islam Al Azhar 4 Kebayoran Lama perlu lebih meningkatkan frekuensi dan intensitas pengawasan langsung dan melekat terhadap aktifitas karyawan dan lebih memperhatikan hak karyawan melalui balas jasa yang seimbang dan proporsional dengan beban kewajibannya. Apabila hal tersebut dilakukan maka akan tumbuh budaya kerja yang mencerminkan inisiatif dan motivasi yang benar-benar lahir dari keinginan pribadi. Tindakan dan upaya perbaikan harus terus dilakukan baik dari aspek fisik maupun mental sebagai daya dukung positif terhadap kemajuan perusahaan.

\section{DAFTAR PUSTAKA}

Hasibuan, "Sistem Manajemen

Kinerja: Performance

Management System,

Panduan Praktis untuk

Merancang dan Meraih

Kinerja,.PT Gramedia

Pustaka Utama,Jakarta, 2002

"Manajemen Dasar,

Pengertian dan Masalah", PT Toko Gunung Agung, Jakarta, 2003

Sugiyono, "Metodologi Penelitian

Untuk Skripsi dan Tesis

Bisnis", PT Gramedia

Pustaka, Jakarta, 2009

Febriani, "Sistem Pengawasan Manajemen",Pustaka

Quantum ,Jakarta, 2001

Siagian, SP, "Evaluasi Kinerja Perusahaan",PT Gramedia Pustaka Utama, Jakarta, 2005

Handoko,T.Hani, "Buku Pintar Manajemen Kinerja", Terjemahan Anthony R. Indra,Metalexia Publishing \& PT Qreator Tata Qarakter, Jakarta, 1996

Maman Ukas,"Manajemen: Konsep, Prinsip dan Aplikasi", Agnini, Bandung, 2004 ,"Manajemen Dasar, Pengertian dan Masalah", Edisi Revisi, Bumi Aksara, Jakarta, 2007

Simanjuntak, J, “ Manajemen Sumber Daya Manusia Untuk Perusahaan Dari Teori Ke Praktek", PT Raja Grafindo Perkasa, Jakarta, 2011 
Lawrence, "Manajemen Personalia"

PT. Toko Gunung Agung, Jakarta , 2014

Mangkunegara, Anwar Prabu, “

Manajemen Sumber Daya Manusia”, Cetakan Ketujuh, PT Remaja Rosda Karya, Bandung, 2007
Hasibuan," Asas-asas Manajemen Sumber Daya Manusia", Bandung, Penerbit Suci Press, 2008

Nawawi, Hadari, "Dasar-Dasar Ilmu Organisasi", Gramedia, Yogyakarta, 2002 